[02]

Factors Affecting to Choose Teaching as the Career Path: An Investigation on Graduate Teachers in Western Province Schools in Sri Lanka

\author{
Jayaratne, ARWK and Kottawatta, $\mathrm{H}$
}

\begin{abstract}
Area of the Study

This study is mainly focused on identifying the factors affecting graduates who have chosen teaching as a career and what was their general perception on teaching as a profession.

\section{Problem of the Study}

To investigate the main factors which were influenced to choose teaching as a career path among graduates' teachers in western province in Sri Lanka.

\section{Method of the Study}

The data were collected from randomly selected sample of 100 graduate teachers in western province by using a structured questionnaire, which consisted of 47 statements with a 5 point Likert scale. The data analysis included the univariate and bivariate analyses.

\section{Findings of the Study}

According to the empirical evidence of this study, it is found that perceived teaching ability, intrinsic value, job security, time for family, shape the future of children, enhance social equity, make social contribution, work with children, prior teaching and learning experience have high influence on graduates' choice of teaching as a career and they perceived teaching as a noble profession which requires hard work along with great skills and high standards. As their perception, teaching career is has a well respected career and a high social status within the society.
\end{abstract}

\title{
Conclusion of the Study
}

The identified factors which had higher influence on graduate teachers' career choice can be used to improve teacher recruitment and retention, reform teacher education and professional development and finding ways to enhance teaching effectiveness.

Keywords: Career Choice, Graduates, Teachers, Intrinsic Value

\section{Introduction}

The multiplicity of motives behind each behavior cannot be underestimated when it comes to the choice of lifelong career. The majority of the people are engaging in a career as it assists them to satisfy their life ambitions such as earning a living, developing an interest, helping humanity, gaining social class and respectability. Other than that career is the instrument of seeking meaning, self-fulfillment and satisfaction in life (Sokro et al. 2011). Therefore the motives behind such a crucial choice vary and overlap. 
According to Watt et al. (2012) teaching seems to be a profession considered essential to a country's development and wellbeing. In the present, teachers' daily job has become more complex due to several reasons such as demanding and challenging with increasingly diverse student populations, higher social expectations of schools, expanding fields of knowledge, and new types of responsibilities. In previous research studies, as mentioned by Moran et al. (2001), the motives or entering the teaching profession came up with three categories of motives such as extrinsic, intrinsic and altruistic factors. Extrinsic motives are job guarantee, money, holidays, social security, appointment and ease while interest, personal satisfaction, desire and love of profession (Moran et al. 2001). Service of people, society and country (Moran et al. 2001), contributes to the growth of another individual (Moran et al. 2001; Brookhart and Freeman 1992) are the factors of altruistic motives.

It is important to understand what motives people to choose teaching as their career and what motives them to persist in the profession (Watt et al. 2012). Due to lack of systematic induction programs for beginning teachers, limited connections between teacher education, teachers' professional development and school needs, the effects of stress, poor working environment, and lack of recognition of teachers also have increased the importance of understanding the motivations of people to choose teaching as their career (OCED 2005). Therefore, this paper aims to discuss the factors affecting to choose teaching as the career path by graduates in western province schools.

\section{Problem Background and Problem of the Study}

In the global context, many countries are currently experiencing problems with teacher recruitment and retention (OECD 2005). The number of people being attracted into teaching is declining while the number leaving the profession in the first three to five years is increasing in global context (OECD 2005). Therefore, governments and employing authorities in different countries are finding it difficult to sustain a suitably high-quality teaching force.

But the situation in Sri Lanka is different since the Sri Lankan government recruits teachers year by year in an increasing rate. The total number of appointed government teachers have been increased by 3\% within the period from 2008 to 2012 and they have recruited 12, 863 graduate teachers within the 5 years period from 2008 to 2012 (Economic and Social statistics of Sri Lanka 2010; 2011; 2013). When considering the graduate labour supply, during the period of 2008 to 2012 it has increased gradually. Around $21 \%$ of graduates have chosen teaching as their career (Sri Lankan University Statistics 2010; 2012).

As Ariyawansa (2008) stated, faculties such as Medicine, Engineering, Law, Agriculture, Science and Management direct their students towards the properly defined objectives of professions and also they have built up links with both professional bodies in national and international context. Though there is a good background for choosing high salary jobs in private sector, significant amount of graduates tend to choose teaching as their career. Therefore the problem of this study is to find out the factors affecting to graduates to choose teaching as the career path. Motivational factors that could have influenced the choice of 
teaching as their career and the general perception of the graduate teachers to choose teaching as a profession are two major objectives of this study.

\section{Research Framework}

A career has the potential to satisfy not only an individual's economic needs, but also social and personal needs (social interaction, self-concept and one's personality identity) (Borchert 2002). Common definition for career is a series of jobs arranged over time (Riley and Ladkin 1994). As Weber and Ladkin state (2012), career is the outcome of structural opportunities made available to an individual. Structural opportunities here are the size of the industry, organizational structure, knowledge specificity and human ability (Weber and Ladkin 2012). Career choice indicates several things such as process of decision making, surveying work field, assessing competencies, understanding of what brings sense of fulfillment, studying options and matching options with self concept (Gokuladas 2010). Making a career choice has become complex with the advent of information technology, emergence of post industrial revolution, job competition and changes in individual's interest, abilities and values (Quinter and Edwards 2011). There are two conditions that should be met when making career decision which are availability of alternative career options and a personal preference between these career options (Ozbilgin et al. 2011).

There are different factors affecting the choice of career path of an individual. The following is the summary of different factors affecting the choice of an individual's career.

\section{Social Relationship}

i. Attitudes and beliefs acquired during the childhood (Julien 1999)

ii. Likeness of adopting the type of career the parents (Beyer 2008; Ginzberg 1972; Crites 1969)

iii. Parental influence such as father's career, prestige and economic status (Amir in 1984 as cited by Mustapha et al. 2010)

iv. Parental support, verbal persuasions and active monitoring (Beyer 2008; Ginzberg 1972; Crites 1969)

v. Siblings, family members, family friends, peers and guidance counselors (Julien 1999)

vi. Teaching role (teachers' communicating method, behavior and teaching (Mustapha et al. 2010)

\section{Personal Factors}

i. $\quad$ Education (Ginzberg 1972)

ii. Interest (Alwiah in 1985 cited as Mustapha et al. 2010; Hyppola et al. 1998)

iii. Personality factors (Holland 1985)

iv. Self-satisfaction, human relations, own ability, value and self-concept (Splaver 1977; Anana \& Nique 2010; Mustapha et al. 2010)

\section{Work Related Factors}
i. $\quad$ Appraisals (Aycan \& Fikret-Pasa 2003; Sawar \& Azmat 2013)
ii. Health allowances (Aycan \& Fikret-Pasa 2003; Sawar \& Azmat 2013)
iii. Old age benefits (Aycan \& Fikret-Pasa 2003; Sawar \& Azmat 2013)
iv. Opportunity for career advance (Aycan \& Fikret-Pasa 2003; Sawar \& Azmat 2013)
v. $\quad$ Pay system (Cable \& Judge 1994; Judge \& Bertz 1992)
vi. Peaceful work environment (Aycan \& Fikret-Pasa 2003; Sawar \& Azmat 2013) 
ISSN: 2012-7227

vii. $\quad$ Power and authority (Aycan \& Fikret-Pasa 2003; Sawar \& Azmat 2013)

viii. Recognition (Aycan \& Fikret-Pasa 2003; Sawar \& Azmat 2013)

\section{Social and Economic Factors}

i. Accessibility of financial resources (Katz 1992; Dyer 1994)

ii. $\quad$ Age (Katz 1992; Dyer 1994; Khallad 2000; Watson et al 2002)

iii. Availability of start-up capital (Katz 1992; Dyer 1994)

iv. Availability of work (Katz 1992; Dyer 1994)

v. Credit for self-employment (Katz 1992; Dyer 1994)

vi. Economic growth (Katz 1992; Dyer 1994)

vii. Family history of self employment (Katz 1992; Dyer 1994; Khallad 2000; Watson et al 2002)

viii. Gender (Katz 1992; Dyer 1994; Khallad 2000; Watson et al 2002)

ix. $\quad$ Legislative framework (Katz 1992; Dyer 1994)

x. $\quad$ National culture and value ( $\mathrm{Ng}$ et al 2008)

xi. $\quad$ Race (Katz 1992; Dyer 1994; Khallad 2000; Watson et al 2002)

xii. $\quad$ Role models (Katz 1992; Dyer 1994; Khallad 2000; Watson et al 2002)

xiii. $\quad$ Sex (Katz 1992; Dyer 1994; Khallad 2000; Watson et al 2002)

xiv. $\quad$ Social support (Katz 1992; Dyer 1994; Khallad 2000; Watson et al 2002)

xv. Societal attitudes (Katz 1992; Dyer 1994; Khallad 2000; Watson et al 2002)

xvi. Socioeconomic status (Katz 1992; Dyer 1994; Khallad 2000; Watson et al 2002)

xvii. Tax regime (Katz 1992; Dyer 1994)

Moran et al. (2001) concluded based on the previous research findings, there are three categories of motives when an individual is entering teaching profession, which are extrinsic, intrinsic and altruistic motives. The study done by Goh and Atputhasamy (2001) in Singapore found that love of working with children, love for teaching, opportunity to influence the young lives for better, intellectual stimulation, perception of teaching as noble profession were the five major influential motives to choose teaching as a career. OECD (2005) identified few factors of an individual to choose teaching as a career, which are working with children and adolescents, making a social contribution, making a difference, job security, job benefits, enjoyment of teaching, compatibility with other interests and activities, compatibility with family life and self-education.

Factors Influencing Teaching Choice (FIT) was used to identify the factors which affect graduates to choose teaching as their career path (Watt et al., 2012). For this study, few changes were made to the FIT Choice theoretical model of Watt et al as to be matched with Sri Lankan context (Refer Figure 01). The FIT Choice theoretical model was initially developed and validated in Australian context and it identifies the different psychological mechanisms which are involved in the choice of teaching as a career (Watt et al. 2012). 
Figure 01: Theoretical Framework

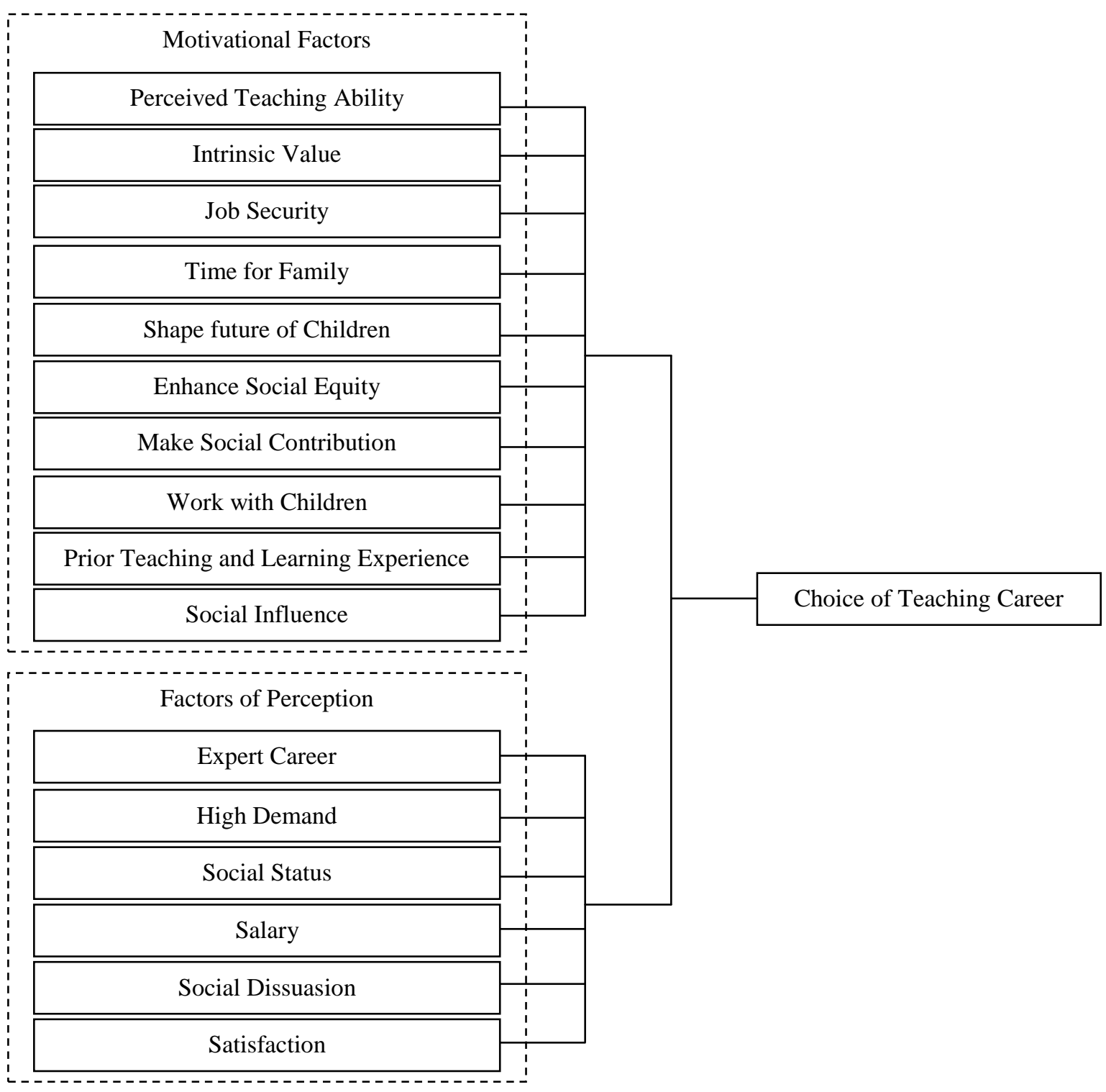

Method

\section{Study Design}

The purpose of this study is to identify the factors affecting graduates to choose teaching as their career path. Therefore this study was causal rather than a correlational study. The target sample for this study included a group of 100 graduate teachers; 35 graduate teachers from Kaluthara district, 35 graduate teachers from Colombo district and 30 graduate teachers from Gampaha district from the accessible population. The sample method of the survey was the convenience random sampling. The type of investigation was descriptive and it was a cross sectional study. Also this was a field study because the data was collected from the natural working environment. When collecting data the organizational setting was not stimulated. Thus this is a non-contrived study. The unit of analysis was individual level where the graduate teachers were served as respondents and data was gathered through questionnaire survey method. The questionnaire used in the study was a standardized questionnaire which was named as the FIT Choice scale, an instrument developed by Richardson and Watt 
(2006) and validated on two large samples of pre-service teachers in two Australian universities. The questionnaire was altered considering the Sri Lankan context.

\section{Measures}

The variables in the research model, socialization influences, task demand, task return, selfperceptions, intrinsic value, personal utility value and social utility value were measured by using a questionnaire with five point Likert scales, which were completed by the respondents according to their experience. The five point scales for all the factors ranged from " totally agree" to " totally disagree" with the point of 5 to 1 respectively for positive statements and 1 to 5 in reverse order respectively for negative statements. Following is the original questionnaire developed to assess the motivation and perception of the teachers.

\begin{tabular}{|c|c|}
\hline Motivations & Original questions \\
\hline \multirow[t]{3}{*}{ Perceived teaching abilities } & I have the qualities of a good teacher \\
\hline & I have good teaching skills \\
\hline & Teaching is a career suited to my abilities \\
\hline \multirow[t]{3}{*}{ Intrinsic value } & I am interested in teaching \\
\hline & I like teaching \\
\hline & I've always wanted to be a teacher \\
\hline \multirow{3}{*}{$\begin{array}{l}\text { Personal utility value Job } \\
\text { security }\end{array}$} & Teaching will offer a steady career path \\
\hline & Teaching will provide a reliable income \\
\hline & \begin{tabular}{|l|} 
Teaching will be a secure job \\
\end{tabular} \\
\hline \multirow{5}{*}{ Time for family } & Part-time teaching could allow more family time \\
\hline & Teaching hours will fit with the responsibilities of having a family \\
\hline & School holidays will fit in with family commitments \\
\hline & As a teacher I will have lengthy holidays \\
\hline & As a teacher I will have a short working day \\
\hline \multirow{2}{*}{$\begin{array}{l}\text { Social utility value Shape future } \\
\text { of children/ adolescents }\end{array}$} & Teaching will allow me to shape child/ adolescent values \\
\hline & Teaching will allow me to influence the next generation \\
\hline \multirow[t]{2}{*}{ Enhance social equity } & Teaching will allow me to raise the ambitions of underprivileged youth \\
\hline & Teaching will allow me to benefit the socially disadvantaged \\
\hline \multirow[t]{3}{*}{ Make social contribution } & Teaching allows me to provide a service to society \\
\hline & Teachers make a worthwhile social contribution \\
\hline & Teaching enables me to 'give back' to society \\
\hline \multirow{3}{*}{$\begin{array}{l}\text { Work with children/ } \\
\text { adolescents }\end{array}$} & I want a job that involves working with children/ adolescents \\
\hline & I want to work in a child/adolescent centered environment \\
\hline & I like working with children/ adolescents \\
\hline \multirow{3}{*}{$\begin{array}{l}\text { Prior teaching and learning } \\
\text { experiences }\end{array}$} & I have had inspirational teachers \\
\hline & I have had good teachers as role-models \\
\hline & I have had positive learning experiences \\
\hline \multirow[t]{3}{*}{ Social influences } & My friends think I should become a teacher \\
\hline & My family think I should become a teacher \\
\hline & People I've worked with think I should become a teacher \\
\hline \multicolumn{2}{|l|}{ Perception } \\
\hline \multirow{2}{*}{$\begin{array}{l}\text { Task demand } \\
\text { Expert career }\end{array}$} & Do you think teaching requires high levels of expert knowledge? \\
\hline & Do you think teachers need high levels of technical knowledge? \\
\hline \multirow[t]{3}{*}{ High demand } & Do you think teachers have a heavy workload? \\
\hline & Do you think teaching is emotionally demanding? \\
\hline & Do you think teaching is hard work? \\
\hline \multirow{5}{*}{$\begin{array}{l}\text { Task return } \\
\text { Social status }\end{array}$} & Do you believe teachers are perceived as professionals? \\
\hline & Do you believe teaching is perceived as a high-status occupation? \\
\hline & Do you believe teaching is a well-respected career? \\
\hline & Do you think teachers feel valued by society? \\
\hline & Do you think teachers feel their occupation has high social status? \\
\hline
\end{tabular}




\begin{tabular}{|l|l|}
\hline Salary & Do you think teaching is well paid? \\
\cline { 2 - 2 } & Do you think teachers earn a good salary? \\
\hline \multirow{3}{*}{ Social dissuasion } & Were you encouraged to pursue careers other than teaching? \\
\cline { 2 - 2 } & Did others tell you teaching was not a good career choice? \\
\cline { 2 - 2 } & Did others influence you to consider careers other than teaching? \\
\hline Satisfaction & How satisfied are you with your choice of becoming a teacher? \\
\cline { 2 - 2 } & How happy are you with your decision to become a teacher? \\
\hline
\end{tabular}

Source: Wett, HMG, Richardson, PW, Klusmann, U, Kunter, M, Beyer, B, Trautwein, U \& Baumert, T 2012, Motivations for choosing teaching as a career: An international comparison using the FIT-choice scale, Teaching and Teaching Education, Vol. 28, pp. 791-805.

The mean value of these five point scale was 03 , i.e. $[1+2+3+4+5] / 5=03$. Hence the mean value was taken as the deciding factor, which determines whether the respondents are in favor of the career choice of teaching. The degree of the result of the measurement of these variables therefore the average score was interpreted with the decision rules in the following way for each factor.

Let $\mathrm{P}$ be the Average Score of the factor

If $\mathrm{P}>3$, then the factor is highly affecting to the career choice of teaching.

If $\mathrm{P}=3$, then the factor is averagely affecting to the career choice of teaching.

If $\mathrm{P}<3$, then the factor is poorly affecting to the career choice of teaching.

\section{Validity and Reliability}

The reliability of the instruments used to collect data was examined with Cronbach's alpha test and all the instruments had more than 0.750 of Cronbach alpha value stating significant reliability. The content validity of the instruments was ensured by the conceptualization and operationalization of the variables on literature.

\section{Techniques of Data Analysis}

After gathering the data they are analyzed by using the computer based statistical data analysis package, SPSS (Version 16) for validity and reliability testing. Frequency distribution and correlation analyses were applied in data analysis.

\section{Results and Discussion}

According to Table 1 all the motivational factors apart from social influence, have mean value more than 3.0. Therefore, perceived teaching ability, intrinsic value, job security, time for family, shape the future of children, enhance social equity, make social contribution, work with children, prior teaching and learning experience have high influence on graduates teaching career choice.

Among those motivational factors, time for family was the highest rated factor (mean $=4.92$ ). This may occur as teaching provides greater flexibility of employment, shorter working hours and long school vacations. The second highest rated factor is intrinsic value (mean $=4.11)$. It implies that passion for teachings within the graduates have premier influence on making their career choice. The third highest rated factor is job security (mean $=4.30$ ). This may be because graduates are offered teaching in government schools along with pension. In Sri 
Lanka, still most of the people believe government jobs have more job security than private sector jobs though private sector jobs offer high salary.

Make social contribution, shape future of children and enhance social equity have mean values of 4.00, 3.95 and 3.85 respectively. This indicates that graduates believe in the concept of "give back to the society" in this modern competitive environment. Prior teaching and learning experience were rated quite high (mean $=3.84$ ) when making teaching career choice. It may be because almost every individual has been a student and effective teachers can provide powerful role models as well as the opportunity for mediated personal judgment concerning one's own teaching related abilities. As indicated by empirical data, the findings of the current study suggests that, in general time for family, intrinsic value, job security, make social contribution, shape future of the children enhance social equity and prior teaching and learning experience are important determinants of the decision of becoming a teacher (Hyppola et al. 1998; OECD 2005; Watt et al. 2012).

Table 1: Statistics of the Distribution of Motivational Factors

\begin{tabular}{|l|r|r|r|}
\hline & Mean & Std. Deviation & Variance \\
\hline Perceived teaching abilities & 3.4033 & .17275 & .030 \\
\hline Intrinsic value & 4.1100 & .44710 & .200 \\
\hline Job security & 4.3000 & .14603 & .021 \\
\hline Time for family & 4.9250 & .23969 & .057 \\
\hline Shape future of children & 3.9500 & .21904 & .048 \\
\hline Enhance social equity & 3.8500 & .45227 & .205 \\
\hline Make social contribution & 4.0067 & .37299 & .139 \\
\hline Working with children & 3.5100 & .41427 & .172 \\
\hline Prior teaching and learning experience & 3.8467 & .97029 & .941 \\
\hline Social influence & 2.8667 & .58411 & .341 \\
\hline
\end{tabular}

According to Table 2, all the factors of perception of teaching except social dissuasion have recorded mean value of more than 3.0 implying that they have high influence on graduate teaching career choice. The highest rated factor was high demand (mean $=4.34$ ). It indicates that graduate teachers think that teaching involves heavy workload and it requires hard work. The second highest rated factor was social status (mean $=4.27$ ) which points out that graduate teachers perceive teaching as a profession which is well respected and high status occupation. Salary, expert career and social dissuasion have mean values 3.9, 3.8 and 2.7 respectively. It implies that graduate teachers are happy with their salary and they believe expert theory knowledge and technical knowledge are required for teaching. The lowest rated factor was social dissuasion and it indicates that third party has rarely encouraged to choose different job other than teaching. 
Table 2: Statistics of the Distribution of Factors of Perception of Teaching

\begin{tabular}{|l|r|r|r|}
\hline & Mean & Std. Deviation & Variance \\
\hline Expert career & 3.8050 & 1.40147 & 1.964 \\
\hline High demand & 4.3433 & .75278 & .567 \\
\hline Social status & 4.2740 & .41745 & .174 \\
\hline Salary & 3.9050 & .51097 & .261 \\
\hline Social dissuasion & 2.3067 & .39435 & .156 \\
\hline Satisfaction & 4.7450 & .37264 & .139 \\
\hline
\end{tabular}

To investigate the interactions among motivational factors and factors of perception of teaching with satisfaction Pearson Product Moment Correlation was conducted.

According to Table 3, inter correlation among motivational factors with satisfaction were as follows. Time for family ( $r=0.632)$, make social contribution $(r=0.642)$, enhance social equity $(r=0.445)$ and work with children $(r=0.502)$ have strong positive relationship with satisfaction while shape the future of children $(\mathrm{r}=-0.158)$, prior teaching and learning experience $(r=-0.133)$ and social Influence $(r=-0.266)$ have negative weak relationship with satisfaction.

According to Table 4, inter correlation among factors of perception of teaching with satisfaction were given. And satisfaction is positively but weakly related to expert career ( $\mathrm{r}$ $=0.078)$, high demand $(\mathrm{r}=0.183)$, social status $(\mathrm{r}=0.110)$ and salary $(\mathrm{r}=0.256)$ while it shows negative weak relationship with social dissuasion $(r=-0.216)$.

Table 3: Correlation between Motivational Factors and satisfaction

\begin{tabular}{|l|r|}
\hline Motivational Factors & Satisfaction \\
\hline Perceived teaching abilities & -.609 \\
\hline Intrinsic value & .406 \\
\hline Job security & .770 \\
\hline Time for family & .632 \\
\hline Shape future of children & .117 \\
\hline Enhance social equity & .445 \\
\hline Make social contribution & .642 \\
\hline Working with children & .502 \\
\hline Prior teaching and learning experience & .133 \\
\hline Social influence & -.266 \\
\hline
\end{tabular}

Table 4: Correlation between Factors of Perception and Satisfaction

\begin{tabular}{|l|r|}
\hline Factors of Perception & Satisfaction \\
\hline Expert career & .078 \\
\hline High demand & .183 \\
\hline Social status & .110 \\
\hline Salary & .256 \\
\hline Social dissuasion & -.216 \\
\hline
\end{tabular}




\section{Conclusion and Recommendations}

The major finding of the study is that there are many motivational factors affecting graduates to choose teaching as a career. Among these factors, time for family, job security, intrinsic value, make social contribution, shape future of children, enhance social equity, prior teaching and learning experiences, working with children and perceived teaching abilities are most important motivational factors. There are different research studies which pointed out the similar findings with the finding of this study. Among the motivational factor, time for family (Kilinç \& Mahiroğlu 2009; Saban 2003; Şahin 2010), job security (Kilinç \& Mahiroğlu 2009; Saban 2003; Şahin 2010), intrinsic value (Kilinç et al. 2012; Suryani, et al 2013), make social contribution (Eren \& Tezel 2010; Ozsoy, et al. 2010; Saban 2003; Kilinç et al. 2012; Suryani, et al 2013), shape future of children (Eren \& Tezel 2010; Ozsoy, et al. 2010; Saban 2003; Kilinç et al. 2012), enhance social equity (Eren \& Tezel 2010; Ozsoy, et al. 2010; Saban 2003; Kilinç et al. 2012), prior teaching and learning experiences (Kilinç et al. 2012; Suryani, et al 2013), working with children (Suryani, et al 2013) and perceived teaching abilities (Kilinç et al. 2012) can be identified as most important motivational factors of graduates to choose the teaching as a career.

The results of the study regarding the perception of graduates for the teaching career are high demand, social status, salary and expert career. Social dissuasion is less important perceiving factor. The studies done by Kilinç et al. in 2012 highlighted high demand, expert career and satisfaction with choice as most important perception of the respondent to choose teaching as a career. They found social dissuasion was a less important perception (Kilinç et al. 2012).

According to entire data analysis process and results it can be concluded that among motivation factors; perceived teaching ability, intrinsic value, job security, time for family, shape the future of children, enhance social equity, make social contribution, work with children, prior teaching and learning experience have high influence on graduates' choice of teaching career while social influence have poor influence on graduates' choice of teaching career and graduate teachers generally perceived teaching as a noble profession which requires hard work along with great skills and high standards and it is well respected and have high social status within the society. Apart to those graduate teachers in western province have greater satisfaction on choosing teaching as their life long career.

According to the study results, it is proved that teaching requires high expert theory knowledge and technical knowledge. Therefore, to sustain teacher quality in todays' knowledge based society, it is important to ensure all graduate teachers continue engage into effective on-going professional learning. Apart from that those graduate teachers are highly motivated by the intrinsic benefits of teaching such as working with children, helping them to develop and making contribution to society. Therefore the system structures and school workplace need to ensure that graduate teachers are able to focus on these tasks. 


\section{Reference}

1. Akomolafe 2003, 'Relationship between fathers' occupational status and their children's occupational preference', Journal of Research in Counselling Psychology, No. 9, pp. 127-131.

2. Anana, ED \& Nique, WM, 2010, 'Personal values in relation to graduate career choices', International Journal of Public Sector Management, Vol. 23, No. 2, pp. 158-168.

3. Ariyawansa, RG 2008, 'Employability of graduates of Sri Lankan universities', Sri Lankan Journal of Human Resource Management, Vol.2, No.1, pp. 91-104.

4. Aycan, Z \& Fikret-Pasa, S 2003, 'Career choices, job selection criteria and leadership preferences in a transitional nation: The case of Turkey', Journal of Career Development, Vol. 30, No. 2, pp. 129-144.

5. Beyer, S 2008, 'Gender difference and intra-gender difference amongst management information system students', Journal of Information System Education, Vol. 19, No. 3, pp 301-310.

6. Borchert, M 2002, 'Career choice factors of high school students, A thesis submitted in partial fulfillment of the requirement of University of Wisconsin-Stout for the degree of Master in Science with major in Career and Technical Education, Menomonie: Wisconsin-Stout University.

7. Brookhart, SM \& Freeman, DJ 1992, 'Characteristics of Entering Teacher Candidates', Review of Educational Research, Vol. 62, No.1, pp. 37-60.

8. Cable, DM \& Judge, TA 1994, 'The preference and job search decisions: A personorganization fit perspective', Personnel Psychology, Vol. 42, No. 2, pp. 317-348.

9. Crites, JO 1969, 'Vocational Psychology: The study of vocational behavior and its development', New York: McGrawhill.

10. Dyer, WG 1994, 'Toward a theory of entrepreneurial careers', Entrepreneurship Theory and Practice', Vol. 19, No. 2, pp. 7-23.

11. Economic and Social statistics of Sri Lanka 2010; Central Bank of Sri Lanka, Vol. 33, http://www.cbsl.gov.lk [12/12/2014].

12. Economic and Social statistics of Sri Lanka 2011, Central Bank of Sri Lanka, Vol. 34, http://www.cbsl.gov.lk [12/12/2014].

13. Economic and Social statistics of Sri Lanka 2013, Central Bank of Sri Lanka, vol. 36, http://www.cbsl.gov.lk [12/12/2014].

14. Eren, A \& Tezel, KV 2010, 'Factors influencing teaching choice, professional plans about teaching, and future time perspective: A meditational analysis', Teaching and Teacher Education, No. 26, pp. 1416-1428.

15. Ginzberg, E 1972, 'Toward a theory of occupational choice: A restatement', Vocational Guidance Quarterly, Vol. 20, No. 3, pp. 169-176.

16. Goh, KC \& Atputhasamy, I 2001, 'Factors motivating the young adults to choose a career in Singapore', The International Educational Research Conference, University of Notre Damme, Western Australia.

17. Gokuladas, VK 2010, 'Factors that influence first-career choice of undergraduate engineers in software services companies: A South Indian comparison', Career Development International, Vol. 15, No. 2, pp. 144-165. 
18. Holland JL 1985, 'Making vocational choices: A theory of vocational personalities and work environment', Englewood, Cliffs, NJ: Prentice Hall.

19. Hyppola, H, Kumpusalo, E, Neittaanmaki, L, Mattila, K, Virjo, I, Kujala, S, Luhtala, R, Halila, H, Isokoski, M 1998, 'Becoming a doctor - was it the wrong career choice?', Social Science and Medicine, Vol. 47, No.9, pp. 1383-1387.

20. Johnson, SM \& Birkeland, SE 2003., 'Pursuing a "Sense of Success: new teachers explain their career decisions', American Educational Research Journal, Vol. 40, No. 3, pp. 581-617

21. Judge, TA \& Bertz, RD 1992, 'Effect of work values on job choice decision', Journal of Applied Psychology, Vol. 77, No. 3, pp. 261-271.

22. Julien, HE 1999, 'Barriers to adolescents' information seeking for career decision making', Journal of the American Society for Information Science, Vol. 50, No. 1, pp. $38-48$.

23. Katz, J 1992, 'A psychosocial cognitive model of employment status choice', Entrepreneurship Theory and Practice, Vol. 17, No.1, pp. 29-37.

24. Khallad, J 2000, 'Education and career aspirations of Palestinian and US youth', Journal of Social Psychology, No. 140, pp. 409-429.

25. Kilınç, A \& Mahiroglu, A 2009, 'The attractors of teaching biology: A perspective from a Turkish “ context', Australian Journal of Teacher Education, Vol. 34, No. 5, pp. 15-39.

26. Kilinç, A, Watf, HMG and Richardson, PW 2012, 'Factors influencing teaching choice in turkey', Asia-Pasific Journal of Teacher Education, Vol. 40, No. 3, pp. 199226.

27. Liu, E, Kardos, SM, Kauffman, D, Preske, HG \& Johnson, SM 2000, 'Barely breaking even: Incentives, rewards, and the high costs of choosing to teach', Harvard Graduate School of Education. http://www.gse.harvard.edu/wngt/Barely\% 20Breaking\%20Even\%200700.PDF.

28. Moran, A, Kirkpotatrick, R, Abbot, L, Dallat, J \& McClune, B 2001, 'Training to tech: Motivating factors and implication for recruitment', Evaluation and Research in Education, Vol. 15, No. 1, pp. 17-32.

29. Mustapha, RB, Long, NL \& Mohd, F 2010, 'Career decision process among women in technical field. Conference proceedings of the $1^{\text {st }}$ UPI International conference on Technical and Vocational Education and Training Bandung, Indonesia.

30. Ng, ESW, Burke, RJ \& Fiksenbaun, L 2008, 'Career choice in management: findings from US MBA students', Career Development International, Vol. 13, No. 4, pp. 346361.

31. OECD 2004, 'Attracting, developing and retaining effective teachers', Paris: Organisation for Economic Co-operation and Development. http://www.oecd.org/document/9/0,2340,en_2649_34521_11969545_1_1_1_1,00.htm 1 Accessed.

32. OECD 2005, 'Teachers matter: Attracting, developing and retaining effective teachers', Paris: OECD Publishing. 
33. OECD 2011, 'Building a high-quality teaching profession: Lessons from around the world. Background report for the international summit on the teaching profession', Paris: OECD Publishing. http://asiasociety.org/files/lwtw-teachersummit.pdf .

34. Ofsted 2001, 'The annual report of her majesty's chief inspector of schools: Standards and quality in education 2000/01', London: Office of Standards in Education.

35. Ozbilgin, M, Kusku, F \& Erdogmus, N 2011, 'Explaining influences on career choice: the case of MBA students in comparative perspective', International Journal of Human Resource Management, Vol. 16, No. 11, pp. 2000-2028.

36. Özsoy, G, Özsoy, S, Özkara, Y, \& Memis, AD 2010, 'Factors affecting pre-service teachers' choice of teaching as a profession', Elementary Education Online, Vol. 9, No. 2, pp. 910-921.

37. Preston, B 2000, 'Teacher supply and demand to 2005-projections and context', Canberra: Australian Council of Deans: ACDE.

38. Quinter, K \& Edwards, M 2011, 'Factors Influencing Students Career Choices among Secondary School students in Kisumu Municipality, Kenya', Journal of Emerging Trends in Educational Research and Policy Studies (JETERAPS), Vol. 2, No. 2, pp. 81-87.

39. Ramsay, G 2000, 'Quality matters. Revitalising teaching: Critical times, critical choices. Report of the review of teacher education', Sydney: NSW Department of Education and Training.

40. Richardson, PW \& Watt, HMG 2006, 'Who chooses teaching and why? Profiling characteristics and motivations across three Australian universities', Asia - Pacific Journal of Teacher Education, Vol. 34, No 1, pp. 27-56.

41. Riley, M \& Ladkin, A 1994, 'Career development and tourism: The development of a basic analytical framework', Progress in Tourisum, Recreation and Hospitality Management, No. 6, pp. 225-237.

42. Saban, A 2003, 'A Turkish profile of prospective elementary school teachers and their views of teaching', Teaching and Teacher Education, No. 19, pp. 829-846.

43. Sahin, AE 2010, 'Professional status of elementary teaching in Turkey: A Delphi study', Teachers and Teaching: Theory and Practice, No. 16, pp. 437-459.

44. Sawar, A \& Azmat, A 2013, 'Factors having impact on the career decisions: Study of business gradustes in Pakistan', Business Management Dynamics, Vol. 2, No. 7, pp. 9-19.

45. Sokro, E, Agbola, R, Osei-Bonsu, N \& Ankrah, E 2011, 'The impact of career choice on job satisfaction among employees in Ghana', Indian Journal of Commerce \& Management Studies, Vol. 2, No. 6.

46. Splaver, S 1977, 'Your personality and your career', New York, NY: Julian Messner.

47. Sri Lankan University Statistics 2010, University Grant Commission, Sri Lanka, http://www.ugc.ac.lk/en/publications/1115-sri-lanka-university-statistics-2010-.html. [12/12/2014].

48. Sri Lankan University Statistics, 2012, University Grant Commission, Sri Lanka, http://www.ugc.ac.lk/en/university-statistics-2012.html [12/12/2014].

49. Suryani, A, Watt, HMG, \& Richardson, PW 2013, 'Teaching as a career: Perspectives of Indonesian future techers', Joint AARE Conference, Adelaide, pp. 1-17. 
50. Watson, CM, Quatman, T \& Edler, E 2002, 'Career aspirations of adolescent girls: Effects of achievement level, grade and single-sex school environment', Sex Roles, No. 46, pp. 323-335.

51. Weber, K \& Ladkin, A 2009, 'Career anchors of convention and exhibition industry professionals in Asia', Journal of Convention \& Event Tourism, Vol. 10, No. 4, pp. 243-255.

52. Wett, HMG, Richardson, PW, Klusmann, U, Kunter, M, Beyer, B, Trautwein, U \& Baumert, T 2012, Motivations for choosing teaching as a career: An international comparison using the FIT-choice scale', Teaching and Teaching Education, No. 28, pp. 791-805.

\section{Jayaratne, ARWK}

Department of Human Resource Management, University of Sri Jayewardenepura

\section{Kottawatta, $\mathbf{H}$}

Professor, Department of Human Resource Management, University of Sri Jayewardenepura 